\title{
Efficacy of Citrus hystrix sprays in decontaminating Streptococcus mutans on children's toothbrushes
}

\author{
Kemthong Mitrakul ${ }^{\mathrm{a}, *}$, Ratchapin L. Srisatjaluk ${ }^{\mathrm{b}}$, Vimol Srisukh ${ }^{\mathrm{c}}$, Kadkao Vongsawan ${ }^{\mathrm{a}}$ \\ a Department of Paediatric Dentistry, Faculty of Dentistry, Mahidol University, Bangkok 10400 Thailand \\ b Department of Oral Microbiology, Faculty of Dentistry, Mahidol University, Bangkok 10400 Thailand \\ c Department of Food Chemistry, Faculty of Pharmacy, Mahidol University, Bangkok 10400 Thailand
}

*Corresponding author, e-mail: mkemthong@yahoo.com

Received 17 Apr 2014

Accepted 6 Feb 2015

\begin{abstract}
Toothbrushes are sometimes contaminated by micro-organisms that can cause infection. This study evaluates the efficacy of Citrus hystrix sprays compared with $0.12 \%$ chlorhexidine gluconate (CHX) for disinfecting bacteria on children's toothbrushes. The participants were 61 children with a high caries risk aged 8-11. Each subject received two toothbrushes to be used continually for 7 consecutive days. The first set of toothbrushes was used as a baseline without any disinfectant. The others were divided into 5 groups and sprayed with distilled water (control), $0.12 \% \mathrm{CHX}, 6 \%$ makrut oil (MO), $10 \% \mathrm{MO}$, or $13 \% \mathrm{MO}$. Toothbrushes were placed vertically into sterile test tubes containing $8 \mathrm{ml}$ of TYS20B medium and incubated overnight. Then we performed 10-fold serial dilutions from $10^{-1}-10^{-5}$, and spread them on BHI or MS agars for investigating facultative bacteria, oral streptococci, and Streptococcus mutans. Results showed that for total facultative bacteria, 10\% MO and 13\% MO gave the highest reduction rate $(100 \%)>\mathrm{CHX}(88 \%)>6 \% \mathrm{MO}(81 \%)$. For S. mutans, $10 \% \mathrm{MO}$ and $13 \% \mathrm{MO}$ also showed the highest reduction rate $(100 \%)>6 \% \mathrm{MO}(90 \%)>\mathrm{CHX}(88 \%)$. For oral streptococci, $13 \% \mathrm{MO}$ gave the highest reduction rate $(100 \%)>10 \%$ MO $(91 \%)>$ CHX $(88 \%)>6 \%$ MO $(69 \%)$. There was no significant difference between oral sprays and $0.12 \% \mathrm{CHX}$ in the reduction of total facultative bacteria, oral streptococci, and $S$. mutans $(p>0.05)$.
\end{abstract}

KEYWORDS: toothbrush contamination, makrut, chlorhexidine, disinfection

\section{INTRODUCTION}

Early childhood caries is one of the most common chronic diseases in the world including Thailand ${ }^{1,2}$. Children who have dental caries often present with low body mass index which eventually affects growth development ${ }^{3}$. It is a multifactorial disease and one of the most important factors is caries-associated bacteria in dental plaque ${ }^{4}$. Dental plaque or oral biofilm is a complex microbial community composed of numerous microorganisms aggregated by surrounded extracellular polymeric matrix that attaches to tooth surfaces ${ }^{5}$. Mature biofilm is highly tolerant to antimicrobial therapeutics ${ }^{4}$. Ecological plaque hypothesis suggested that an imbalance of microorganisms in oral biofilm results in a pathological condition such as dental caries and periodontitis ${ }^{6}$.

Numerous studies have demonstrated a strong association between Streptococcus mutans and caries in regard to prevalence and transmission, as identical strains of $S$. mutans have been isolated from mothers and their children ${ }^{4,6-10}$. Two important characteristics of $S$. mutans relates to plaque de- velopment: firstly, its ability to produce waterinsoluble polymers (glucan) which aid in the persistent adhesion and colonization on tooth surfaces by the action of a glucosyltransferases (GTFase) enzyme. Secondly, it can synthesize intracellular polysaccharide (IPS) which sustains continual acid production during low exogenous substrate ${ }^{4,6}$. The critical step in dental plaque development is also an essential pathway in caries development. It is of great importance to prevent the presence of S. mutans for more effective prevention of dental caries.

Toothbrushes are a potential source of infection. Previous studies showed a correlation between contaminated brushes and oral disease. Patients with oral disease have a substantial decrease in both initial and recurrent symptoms when they change toothbrushes ${ }^{11-15}$. Studies have shown that toothbrush sharing is a risk factor for the transmission of hepatitis $\mathrm{B}^{15}$. Previous studies reported that S. mutans was found in both children's and adults' toothbrushes ${ }^{12,13}$. Not only oral streptococci were found on toothbrush bristles, but also herpes simplex virus type I, Pseudomonas aeruginosa, and other 
opportunistic pathogens ${ }^{16-18}$. Reducing contamination of toothbrushes may therefore be important to control of a wide range of oral diseases. One solution might be single-use brushes, or at least renewing brushes regularly. Since, this might have important economic and environmental consequences, an alternative approach might be preferable. It is not feasible to sterilize toothbrushes between uses but a decontamination procedure that reduces the infectious burden might be acceptable ${ }^{17}$.

Many studies have demonstrated the efficiency of various methods in disinfecting oral microorganisms on toothbrushes such as UV radiation, microwave radiation, ozone inhibition, and chemical disinfection ${ }^{12-14,17,19-23}$. In spite of novel methods of decontamination, a method that is highly effective and user-friendly is using chemical agents ${ }^{11}$. Glass and colleagues reported that there was no oral bacteria on toothbrushes after subjects had used an antibacterial mouthwash ${ }^{16}$. Caudry and colleagues showed that there was a significant reduction of oral bacteria after immersing toothbrushes in Listerine mouthwash for $20 \mathrm{~min}^{20}$. Mehta and colleagues demonstrated that there was a significant reduction of oral bacteria after soaking toothbrushes in $0.12 \%$ chlorhexidine gluconate (CHX) mouthwash overnight $^{18}$. There were also few studies which reported the efficiency of $0.12 \% \mathrm{CHX}$ in a different preparation such as mouthwash and spray in disinfection of children's toothbrushes ${ }^{13,23}$.

The use of natural products proven to have anti-cariogenic properties has been growing ${ }^{24-27}$. Citrus hystrix DC (makrut) is a common type of lime native of SE Asia ${ }^{28}$. A previous study showed that 3 volatile oils extracted from herbs (lemon grass, betel, and makrut oils) have an antibacterial effect against Bacillus subtilis, Staphylococcus aureus, Escherichia coli, and Salmonella Typhimurium ${ }^{28}$. Later studies successfully developed a readily-dissolved edible makrut film for suppression of bad breath and antibacterial activities against various respiratory pathogens including multi-resistant bacteria were reported $^{28,29}$. Moreover, our previous study on the efficacy of makrut oil capsules and spray-10\% makrut oil (MO) and 12\% makrut leaf oil (MLO)on inhibiting S. mutans (ATCC 25175) growth and biofilm formation showed satisfactory results (unpublished data). The efficiency of these oil formulations on the inhibition of growth and biofilm formation along with the susceptibility test of $S$. mutans standard trains (ATCC 25175) and clinical isolates from Thai children should therefore be tested before future clinical trial. From our preliminary study, we tested for biofilm susceptibility of oral spray formulations: $6 \% \mathrm{MO}, 10 \% \mathrm{MO}, 13 \% \mathrm{MO}, 4 \% \mathrm{MLO}$ and $8 \%$ MLO, and they showed promising results in inhibiting $3 \mathrm{~h}$ and $6 \mathrm{~h}$ formed biofilm of $S$. mutans (ATCC 25175) and some clinical isolates from Thai children (unpublished data).

The objectives of this study were to evaluate the efficiency of three $C$. hystrix oil oral spray formulations (6\% MO, $10 \% \mathrm{MO}, 13 \% \mathrm{MO}$ ) in decontaminating $S$. mutans on children's toothbrushes compared with $0.12 \% \mathrm{CHX}$ as a toothbrush disinfectant.

\section{MATERIAL AND METHODS}

\section{Essential oil preparation}

Makrut oil (batch no. 5 209 234/1009; density = $0.87 \mathrm{~g} / \mathrm{ml}$ ) was purchased from Thai-China Flavours and Fragrances Co., Ltd. The components of the essential oils were analysed using GC-MS (Auxs) as described previously ${ }^{28}$. The main component in makrut peel is L-limonene (40\%). Three oil formulations ( $6 \% \mathrm{MO}, 10 \% \mathrm{MO}$, and $13 \% \mathrm{MO}$ ) were prepared. Degradation and taste experiments were performed $^{28}$.

\section{Study design}

This cross-sectional study was approved by the Ethical Human Research Committee, Faculty of Dentistry and the Faculty of Pharmacy, Mahidol University, Thailand (MU-DT/PY-IRB 2013/037.0708). Consents were signed from all child parents/legal guardians. All subjects were free to withdraw from the study at any time. The sample size was calculated based on previous studies with $\alpha=0.05$ and power of $80 \%$, using the software package Primer of Biostatistics (McGraw-Hill, NY, USA). A minimum of 27 children was required ${ }^{21,22}$.

\section{Subject selection and clinical examination}

Subjects were recruited from 3rd to 5th grade students aged between 8 and 11 years old from the Suan Missakawan school, Bangkok, Thailand. Total of 61 students who showed high level of salivary $S$. mutans $\left(>5 \times 10^{5}\right.$ colony-forming units $(\mathrm{CFU}) / \mathrm{ml}$ ) were selected to participate in this study. Salivary S. mutans levels were determined using Saliva-Check Mutans kit (GC Cooperation, JAPAN) following the instruction of the manufacturer. All subjects were healthy. None of them had a professional prophylaxis or fluoride application within the last 3 months or taking any kind of antibiotics during the study period. 
Before the study began, all subjects were taught a tooth brushing technique by examiners using a scrub method. Before the beginning of this study, 4 undergraduate dental students attended lectures to familiarize themselves with the diagnostic criteria of dental caries and plaque deposition. All lectures were given by a dentist (KM) using a document and visuals describing the criteria and illustrating the caries condition. Oral examination was done under the natural light based on the criteria published by the World Health Organization ${ }^{30}$. Kappa statistic values for the decayed, missing, and filled teeth and plaque index were 0.85 and 0.88 , respectively. The strength of agreement was good. The weighted kappa coefficient was 0.83 for total score $(p<0.001)$ showed an excellent agreement. The plaque deposit was assessed according to what was visible to the naked eye after all participants have chewed one tablet of a disclosure agent (Fuchsin Basic, Merck, USA) using Debris Index in simplified oral hygiene index ${ }^{31}$ and modified for mixed dentition $^{31,32}$. The six index teeth (surface) were 55 (B), 51 (La), 65 (B), 75 (Li), 71 (La), and 85 (Li). In the absence of either of these anterior teeth, the primary central incisor on the opposite side of the midline was substituted. In the absence of either of the second primary molar, the first primary molar in the same quadrant was substituted. The area of each tooth was assigned a score from $0-3$. A score of 0 indicates no debris or stain present, 1 indicates soft debris covering not more than one third of the tooth surface, or the presence of extrinsic stains without other debris regardless of surface area covered, 2 indicates soft debris covering more than one, and 3 indicates soft debris covering more than twothirds of the exposed tooth surface. To determine a total plaque index for each subject, the scores for each tooth were summed and divided by the number of teeth examined. All participants were given 2 toothbrushes and advised for washing and storing method using only tap water by gently rinsing thoroughly for $10 \mathrm{~s}$ and storing open-air without touching other toothbrushes. In the first week, each subject received Mdent toothbrush and toothpaste (1000 ppm NaF, Mdent brand is a product of the Faculty of Dentistry, Mahidol University, Bangkok, Thailand) which was used for 7 consecutive days. Reminders were given to parents or caretakers to supervise their children to brush twice a day according to the method taught. After 7 days, the toothbrushes were collected. Then a second set of toothbrushes was distributed to all subjects and used for another 7 days.

\section{Microbiological procedures}

The first set of toothbrushes was used to determine a baseline of bacteria level from each subject without any disinfectants. The second set of toothbrushes was randomly divided into 4 disinfectant groups: Group $1(0.12 \%$ CHX gluconate and $0.15 \%$ benzidamine mouthwash, $n=8)$, Group $2(6 \% \mathrm{MO}$, $n=16)$, Group $3(10 \% \mathrm{MO}, n=16)$, and Group 4 (13\% MO, $n=16)$. Unused toothbrushes $(n=8)$ were used as a sham control. Toothbrushes were fixed vertically in a closed container and let them dried. The toothbrushes were then sprayed with disinfectants 6 times on the bristles at a distance of $5 \mathrm{~cm}$ (approximately $0.6 \mathrm{ml}$ of solution per toothbrush) in the following areas: (1) right side, (2) left side, (3) top, (4) bottom, (5) front, and (6) back of the toothbrush head ${ }^{22}$; gently hitting the toothbrush against the sink to remove excess of antimicrobial solution. After disinfection for $2 \mathrm{~h}$, the toothbrushes were placed vertically into $25 \times 150 \mathrm{~mm}$ sterile test tubes containing $8 \mathrm{ml}$ TYS20B medium and vortexed for $1 \mathrm{~min}^{22,33}$. Tenfold serial dilution from $10^{-1}-10^{-5}$ was performed to determine cell densities. Aliquot of $20 \mu \mathrm{l}$ from each dilution was spread on brain-heart infusion and Mitis Salivarius agars to identify total facultative bacteria, oral streptococci, and $S$. mutans. The plates were incubated at $37^{\circ} \mathrm{C}$ in an atmosphere containing $5 \% \mathrm{CO}_{2}$ for $48 \mathrm{~h}$. Each sample was done in triplicate.

\section{Statistic analysis}

Data is expressed as mean of colony forming units per millilitre $(\mathrm{CFU} / \mathrm{ml})$. Percentage reductions of the total facultative bacteria, oral streptococci and $S$. mutans were calculated and compared to that of the control group. For oral streptococci and $S$. $m u-$ tans, a stereo microscope was used in helping colony determination. Bactericidal effect was considered if it had killed $99 \%$ of the bacteria. Comparison of the efficacy of each oral spray with $0.12 \%$ CHX was done using $\chi^{2}(p<0.05)$ and analysed with SPSS 14.0 software for Windows.

\section{RESULTS}

Total of 61 children participated in this study, $39 \%$ were boys and $60 \%$ were girls (mean age $=$ $10.0 \pm 0.7$ years old). Mean DMFT, DMFT and plaque index were $2.11 \pm 0.69,5.6 \pm 1.9$, and $1.75 \pm 0.59$, respectively. Total facultative bacteria, oral streptococci and $S$. mutans found on the first set of toothbrushes as baseline showed no difference 
between the 4 groups. Eighteen percent of subjects did not have oral streptococci and $41 \%$ of the participants did not have $S$. mutans.

Total facultative bacteria (TFB) found in distilled water group before and after spraying ranged from $7.5 \times 10^{3}-5.5 \times 10^{6}$ and $3.5 \times 10^{3}-$ $1.35 \times 10^{6} \mathrm{CFU} / \mathrm{ml}$, respectively. Table 1 shows the number of TFB found in $6 \% \mathrm{MO}, 10 \% \mathrm{MO}$, $13 \% \mathrm{MO}$, and $0.12 \% \mathrm{CHX}$. TFB found in $6 \% \mathrm{MO}$ group before and after spraying ranged from $10^{3}$ $10^{7}$ and $0-2 \times 10^{4} \mathrm{CFU} / \mathrm{ml}$, respectively. Treatment with $6 \%$ MO showed $81 \%$ reduction of TFB. TFB found in 10\% MO group before and after spraying ranged from $0.05 \times 10^{3}-1.8 \times 10^{7}$ and $0-3.25 \times 10^{3} \mathrm{CFU} / \mathrm{ml}$, respectively. $10 \% \mathrm{MO}$ showed $100 \%$ reduction of TFB. TFB found in $13 \% \mathrm{MO}$ group before and after spraying ranged from $2 \times 10^{3}-6.5 \times 10^{6}$ and $0-0.025 \times 10^{4} \mathrm{CFU} / \mathrm{ml}$, respectively. Treatment with $13 \%$ MO showed $100 \%$ reduction of TFB. TFB found in $0.12 \%$ CHX group before and after spraying were ranged from $10^{5}-9 \times 10^{6}$ and $0-3 \times 10^{6} \mathrm{CFU} / \mathrm{ml}$, respectively. Treatment with $0.12 \%$ CHX showed $88 \%$ reduction of TFB. Three oral sprays and $0.12 \%$ CHX show no significant reduction rate of TFB $(p=0.201)$.

Table 2 shows number of oral streptococci found in $6 \% \mathrm{MO}, 10 \% \mathrm{MO}, 13 \% \mathrm{MO}$, and $0.12 \%$ CHX. Oral streptococci found in 6\% MO group before and after spraying ranged from $0.1 \times 10^{3}-2.5 \times 10^{6}$ and $0-2.6 \times 10^{4} \mathrm{CFU} / \mathrm{ml}$, respectively. Treatment with 6\% MO showed $69 \%$ reduction of oral streptococci. Oral streptococci found in 10\% MO group before and after spraying ranged from $0.025 \times 10^{3}-3.5 \times 10^{6}$ and $0-0.775 \times 10^{3} \mathrm{CFU} / \mathrm{ml}$, respectively. $10 \% \mathrm{MO}$ showed $91 \%$ reduction of oral streptococci. Oral streptococci found in 13\% MO group before and after spraying ranged from $0.025 \times 10^{3}-2.5 \times 10^{5}$ and $0-0.05 \times 10^{3} \mathrm{CFU} / \mathrm{ml}$, respectively. $13 \% \mathrm{MO}$ showed $100 \%$ reduction of oral streptococci. Oral streptococci found in $0.12 \%$ CHX group before and after spraying ranged from $0.75 \times 10^{3}-2 \times 10^{4}$ and $0-3 \times 10^{3} \mathrm{CFU} / \mathrm{ml}$, respectively. $0.12 \% \mathrm{CHX}$ showed $88 \%$ reduction of oral streptococci. Three oral sprays and $0.12 \%$ CHX showed no different significance in reduction rate of oral streptococci $(p=0.121)$.

Table 3 shows number of $S$. mutans found in 6\% MO and 10\% MO, 13\% MO, and 0.12\% CHX. $S$. mutans found in $6 \% \mathrm{MO}$ group before and after spraying were ranged from $0.025 \times 10^{3}$ to an uncountable number $\left(\right.$ mean $\left.=5 \times 10^{3} \mathrm{CFU} / \mathrm{ml}\right)$ and $0-0.075 \times 10^{3} \mathrm{CFU} / \mathrm{ml}$, respectively. Treatment
Table 1 Number of total facultative bacteria and percentage reduction on toothbrushes treated with $6 \% \mathrm{MO}$, $10 \% \mathrm{MO}, 13 \% \mathrm{MO}$, and $0.12 \% \mathrm{CHX}$.

\begin{tabular}{|c|c|c|c|}
\hline \multirow[t]{2}{*}{ Sample } & \multicolumn{2}{|c|}{ Total facultative bacteria (CFU/ml) } & \multirow{2}{*}{$\begin{array}{l}\text { Reduction after } \\
\text { treatment (\%) }\end{array}$} \\
\hline & Before & After & \\
\hline \multicolumn{4}{|l|}{$6 \% \mathrm{MO}$} \\
\hline 2 & $3.5 \times 10^{6}$ & $1.5 \times 10^{3}$ & 99.96 \\
\hline 13 & $5 \times 10^{6}$ & $10^{3}$ & 99.98 \\
\hline 21 & $10^{7}$ & $2 \times 10^{4}$ & 99.80 \\
\hline 22 & $6.75 \times 10^{5}$ & $0.025 \times 10^{3}$ & 99.99 \\
\hline 24 & $2.5 \times 10^{4}$ & $10^{5}$ & no reduction \\
\hline 29 & $4.37 \times 10^{5}$ & $0.025 \times 10^{3}$ & 99.99 \\
\hline 47 & $7 \times 10^{5}$ & 0 & 100 \\
\hline 48 & $10^{5}$ & $1.5 \times 10^{3}$ & 98.64 \\
\hline 56 & $5.2 \times 10^{6}$ & $1.1 \times 10^{4}$ & 99.79 \\
\hline 59 & $8 \times 10^{4}$ & 0 & 100 \\
\hline 71 & $4.75 \times 10^{5}$ & 0 & 100 \\
\hline 78 & $2.75 \times 10^{5}$ & $0.525 \times 10^{3}$ & 99.81 \\
\hline 79 & $3.75 \times 10^{3}$ & 0 & 100 \\
\hline 85 & $10^{3}$ & $0.95 \times 10^{3}$ & 5 \\
\hline 86 & $4 \times 10^{4}$ & 0 & 100 \\
\hline 87 & $8.5 \times 10^{5}$ & $0.125 \times 10^{3}$ & 99.99 \\
\hline \multicolumn{4}{|c|}{$10 \% \mathrm{MO}$} \\
\hline 1 & $2.75 \times 10^{5}$ & 0 & 100 \\
\hline 7 & $1.2 \times 10^{7}$ & 0 & 100 \\
\hline 12 & $2.9 \times 10^{4}$ & 0 & 100 \\
\hline 14 & $6.5 \times 10^{5}$ & $0.275 \times 10^{3}$ & 99.96 \\
\hline 19 & $7.5 \times 10^{4}$ & 0 & 100 \\
\hline 35 & $9.75 \times 10^{5}$ & $0.2 \times 10^{3}$ & 99.98 \\
\hline 37 & $1.3 \times 10^{6}$ & $2.5 \times 10^{3}$ & 99.81 \\
\hline 39 & $6 \times 10^{5}$ & 0 & 100 \\
\hline 40 & $0.05 \times 10^{3}$ & 0 & 100 \\
\hline 41 & $5.2 \times 10^{6}$ & 0 & 100 \\
\hline 55 & $1.7 \times 10^{5}$ & 0 & 100 \\
\hline 58 & $1.8 \times 10^{7}$ & $3.25 \times 10^{3}$ & 99.98 \\
\hline 66 & $3.75 \times 10^{5}$ & $2.75 \times 10^{3}$ & 99.27 \\
\hline 68 & $3.7 \times 10^{6}$ & 0 & 100 \\
\hline 83 & $1.5 \times 10^{6}$ & 0 & 100 \\
\hline 90 & $1.8 \times 10^{4}$ & 0 & 100 \\
\hline \multicolumn{4}{|c|}{$13 \% \mathrm{MO}$} \\
\hline 3 & $3.5 \times 10^{4}$ & 0 & 100 \\
\hline 4 & $1.6 \times 10^{6}$ & 0 & 100 \\
\hline 5 & $1.1 \times 10^{6}$ & $0.125 \times 10^{3}$ & 99.99 \\
\hline 8 & $3.7 \times 10^{5}$ & 0 & 100 \\
\hline 11 & $6.5 \times 10^{5}$ & 0 & 100 \\
\hline 17 & $1.37 \times 10^{6}$ & $0.75 \times 10^{3}$ & 99.95 \\
\hline 18 & $7.7 \times 10^{4}$ & 0 & 100 \\
\hline 23 & $5.5 \times 10^{4}$ & 0 & 100 \\
\hline 33 & $6.5 \times 10^{6}$ & $0.75 \times 10^{3}$ & 99.99 \\
\hline 36 & $7 \times 10^{3}$ & $0.025 \times 10^{4}$ & 99.64 \\
\hline 43 & $2.2 \times 10^{5}$ & 0 & 100 \\
\hline 61 & $4.5 \times 10^{5}$ & $0.5 \times 10^{3}$ & 99.89 \\
\hline 65 & $3.1 \times 10^{4}$ & $0.025 \times 10^{3}$ & 99.92 \\
\hline 76 & $2 \times 10^{3}$ & 0 & 100 \\
\hline 77 & $4 \times 10^{4}$ & 0 & 100 \\
\hline 88 & $2.4 \times 10^{6}$ & 0 & 100 \\
\hline \multicolumn{4}{|c|}{$0.12 \%$ CHX } \\
\hline 6 & $6.5 \times 10^{6}$ & $25 \times 10^{3}$ & 99.62 \\
\hline 9 & $7 \times 10^{6}$ & 0 & 100 \\
\hline 16 & $4 \times 10^{6}$ & $3 \times 10^{6}$ & 25 \\
\hline 45 & $2.1 \times 10^{6}$ & $0.1 \times 10^{3}$ & 99.99 \\
\hline 49 & $9 \times 10^{6}$ & $0.3 \times 10^{3}$ & 99.99 \\
\hline 51 & $1.1 \times 10^{5}$ & $0.3 \times 10^{3}$ & 99.73 \\
\hline 72 & $4.75 \times 10^{5}$ & $1.25 \times 10^{3}$ & 99.74 \\
\hline 73 & $10^{5}$ & $0.05 \times 10^{3}$ & 99.95 \\
\hline
\end{tabular}


Table 2 Number of oral streptococci and percentage reduction on toothbrushes treated with $6 \% \mathrm{MO}, 10 \% \mathrm{MO}$, $13 \% \mathrm{MO}$, and $0.12 \% \mathrm{CHX}$.

\begin{tabular}{|c|c|c|c|}
\hline \multirow[t]{2}{*}{ Sample } & \multicolumn{2}{|c|}{ Oral streptococci (CFU/ml) } & \multirow{2}{*}{$\begin{array}{l}\text { Reduction after } \\
\text { treatment (\%) }\end{array}$} \\
\hline & Before & After & \\
\hline \multicolumn{4}{|c|}{$6 \% \mathrm{MO}$} \\
\hline 2 & $2.5 \times 10^{6}$ & $0.025 \times 10^{3}$ & 99.99 \\
\hline 13 & $2.5 \times 10^{6}$ & 0 & 100 \\
\hline 21 & $2.65 \times 10^{5}$ & $2 \times 10^{4}$ & 92.45 \\
\hline 22 & $9.5 \times 10^{3}$ & 0 & 100 \\
\hline 24 & $2.25 \times 10^{3}$ & $2.6 \times 10^{4}$ & no reduction \\
\hline 29 & $2.5 \times 10^{3}$ & 0 & 100 \\
\hline 47 & $0.7 \times 10^{3}$ & 0 & 100 \\
\hline 48 & $3.25 \times 10^{3}$ & $0.625 \times 10^{3}$ & 80.77 \\
\hline 56 & $1.5 \times 10^{4}$ & $1.5 \times 10^{4}$ & 4.76 \\
\hline 59 & $10^{3}$ & 0 & 100 \\
\hline 71 & $3.75 \times 10^{4}$ & 0 & 100 \\
\hline 78 & $0.05 \times 10^{3}$ & 0 & 100 \\
\hline 79 & $0.55 \times 10^{3}$ & 0 & 100 \\
\hline 85 & $0.1 \times 10^{3}$ & 0 & 100 \\
\hline 87 & $3.75 \times 10^{3}$ & 0 & 100 \\
\hline \multicolumn{4}{|c|}{$10 \% \mathrm{MO}$} \\
\hline 1 & $2.5 \times 10^{3}$ & 0 & 100 \\
\hline 7 & $1.8 \times 10^{4}$ & 0 & 100 \\
\hline 12 & $1.15 \times 10^{3}$ & 0 & 100 \\
\hline 19 & $0.625 \times 10^{3}$ & 0 & 100 \\
\hline 37 & $4.75 \times 10^{3}$ & 0 & 100 \\
\hline 41 & $5.25 \times 10^{4}$ & 0 & 100 \\
\hline 58 & $3.5 \times 10^{6}$ & $0.775 \times 10^{3}$ & 99.97 \\
\hline 66 & $0.35 \times 10^{3}$ & $0.525 \times 10^{3}$ & no reduction \\
\hline 68 & $2.375 \times 10^{3}$ & 0 & 100 \\
\hline 83 & $3.1 \times 10^{6}$ & 0 & 100 \\
\hline 90 & $0.025 \times 10^{3}$ & 0 & 100 \\
\hline \multicolumn{4}{|c|}{$13 \% \mathrm{MO}$} \\
\hline 3 & $2.5 \times 10^{5}$ & 0 & 100 \\
\hline 4 & $0.8 \times 10^{3}$ & 0 & 100 \\
\hline 5 & $6.5 \times 10^{3}$ & 0 & 100 \\
\hline 8 & $2.2 \times 10^{5}$ & 0 & 100 \\
\hline 18 & $10^{3}$ & 0 & 100 \\
\hline 23 & $0.25 \times 10^{3}$ & 0 & 100 \\
\hline 36 & $4.25 \times 10^{3}$ & 0 & 100 \\
\hline 43 & $3.75 \times 10^{3}$ & 0 & 100 \\
\hline 61 & $1.8 \times 10^{5}$ & $0.05 \times 10^{3}$ & 99.97 \\
\hline 65 & $0.125 \times 10^{3}$ & 0 & 100 \\
\hline 76 & $0.025 \times 10^{3}$ & 0 & 100 \\
\hline 77 & $0.125 \times 10^{3}$ & 0 & 100 \\
\hline 88 & $4.5 \times 10^{3}$ & 0 & 100 \\
\hline \multicolumn{4}{|c|}{$0.12 \% \mathrm{CHX}$} \\
\hline 6 & $5.75 \times 10^{3}$ & 0 & 100 \\
\hline 9 & $5 \times 10^{3}$ & 0 & 100 \\
\hline 16 & $2 \times 10^{4}$ & $3 \times 10^{3}$ & 85 \\
\hline 45 & $9.8 \times 10^{3}$ & 0 & 100 \\
\hline 49 & $22.5 \times 10^{3}$ & 0 & 100 \\
\hline 51 & $0.85 \times 10^{3}$ & 0 & 100 \\
\hline 72 & $2 \times 10^{3}$ & 0 & 100 \\
\hline 73 & $0.75 \times 10^{3}$ & 0 & 100 \\
\hline
\end{tabular}

with $6 \% \mathrm{MO}$ showed $90 \%$ reduction of $S$. mutans. S. mutans found in the $10 \%$ MO group before and after spraying ranged from $0.1 \times 10^{3}$ to an uncountable number and no $S$. mutans was detected, re-
Table 3 Number of $S$. mutans and percentage reduction on toothbrushes treated with $6 \% \mathrm{MO}, 10 \% \mathrm{MO}, 13 \% \mathrm{MO}$, and $0.12 \% \mathrm{CHX}$.

\begin{tabular}{|c|c|c|c|}
\hline \multirow[t]{2}{*}{ Sample } & \multicolumn{2}{|c|}{ S. mutans $(\mathrm{CFU} / \mathrm{ml})$} & \multirow{2}{*}{$\begin{array}{l}\text { Reduction after } \\
\text { treatment (\%) }\end{array}$} \\
\hline & Before & After & \\
\hline \multicolumn{4}{|l|}{$6 \% \mathrm{MO}$} \\
\hline 2 & $4.5 \times 10^{3}$ & $0.075 \times 10^{3}$ & 98.33 \\
\hline 21 & $5 \times 10^{3}$ & 0 & 100 \\
\hline 22 & $3.75 \times 10^{3}$ & 0 & 100 \\
\hline 47 & $0.025 \times 10^{3}$ & 0 & 100 \\
\hline 56 & $>3 \times 10^{8}$ & 0 & 100 \\
\hline 59 & $0.05 \times 10^{3}$ & 0 & 100 \\
\hline 71 & $>3 \times 10^{8}$ & 0 & 100 \\
\hline 78 & $0.5 \times 10^{3}$ & 0 & 100 \\
\hline 79 & $0.5 \times 10^{3}$ & 0 & 100 \\
\hline 87 & $0.25 \times 10^{3}$ & 0 & 100 \\
\hline \multicolumn{4}{|c|}{$10 \% \mathrm{MO}$} \\
\hline 7 & $10^{5}$ & 0 & 100 \\
\hline 12 & $0.2 \times 10^{3}$ & 0 & 100 \\
\hline 14 & $0.475 \times 10^{3}$ & 0 & 100 \\
\hline 19 & $6.5 \times 10^{3}$ & 0 & 100 \\
\hline 37 & $5.5 \times 10^{3}$ & 0 & 100 \\
\hline 41 & $0.1 \times 10^{3}$ & 0 & 100 \\
\hline 55 & $0.575 \times 10^{3}$ & 0 & 100 \\
\hline 66 & $0.175 \times 10^{3}$ & 0 & 100 \\
\hline 83 & $>3 \times 10^{8}$ & 0 & 100 \\
\hline \multicolumn{4}{|c|}{$13 \% \mathrm{MO}$} \\
\hline 4 & $0.57 \times 10^{3}$ & 0 & 100 \\
\hline 5 & $1.275 \times 10^{3}$ & 0 & 100 \\
\hline 11 & $0.075 \times 10^{3}$ & 0 & 100 \\
\hline 18 & $0.5 \times 10^{3}$ & 0 & 100 \\
\hline 36 & $2.5 \times 10^{3}$ & 0 & 100 \\
\hline 77 & $0.2 \times 10^{3}$ & 0 & 100 \\
\hline 88 & $4 \times 10^{3}$ & 0 & 100 \\
\hline \multicolumn{4}{|c|}{$0.12 \% \mathrm{CHX}$} \\
\hline 6 & $8.25 \times 10^{3}$ & 0 & 100 \\
\hline 9 & $3.25 \times 10^{4}$ & 0 & 100 \\
\hline 16 & $>3 \times 10^{8}$ & $3.7 \times 10^{3}$ & no reduction \\
\hline 45 & $2.05 \times 10^{3}$ & 0 & 100 \\
\hline 51 & $0.4 \times 10^{3}$ & 0 & 100 \\
\hline 72 & $10^{3}$ & 0 & 100 \\
\hline 73 & $0.2 \times 10^{3}$ & 0 & 100 \\
\hline
\end{tabular}

spectively. Treatment with 10\% MO showed 100\% reduction of S. mutans. S. mutans found in the $13 \%$ MO group before and after spraying were ranged from $0.2 \times 10^{3}-4 \times 10^{3}\left(\right.$ mean $\left.=4 \times 10^{3}\right)$ and no $S$. mutans was detected, respectively. Treatment with $13 \%$ MO showed a $100 \%$ reduction of $S$. mutans. S. mutans found in $0.12 \%$ CHX group before and after spraying were ranged from an uncountable number to $0.2 \times 10^{3}$ (mean $=1 \times 10^{3}$ ) and $0-3.7 \times 10^{3} \mathrm{CFU} / \mathrm{ml}$, respectively. Treatment with $0.12 \%$ CHX showed $88 \%$ reduction of $S$. mutans. All oral sprays and $0.12 \%$ CHX showed no significant difference of reduction rates of total facultative bacteria, oral streptococci and $S$. mutans $(p=0.22)$. 


\section{DISCUSSION}

The American Dental Association suggests that to reduce dental plaque or oral biofilm accumulation, toothbrushes should be cleaned after each use and should be replaced every 3-4 months ${ }^{34}$. Copious amount of bacteria has been detected on toothbrushes even after $24 \mathrm{~h}$, and mutans streptococci (MS) has been found on toothbrushes soaked in sterile tap water for $20 \mathrm{~h}^{13}$. Another group of researchers reported the detection of MS on toothbrushes soaked in sterile saline for $2 \mathrm{~h}^{35}$. The hypothesis is that if we reduce the biofilm formation on toothbrush, the chance of re-infection would be reduced. Most of soaking time in antibacterial agents was at least $2 \mathrm{~h}$. There was only a study done by Nelson-Filho et al which compared an efficiency of two methods of disinfecting MS on toothbrushes which were soaking and spraying of $0.12 \%$ CHX and result showed that there was no significant difference between those methods ${ }^{22}$. In this study, we found that three oral sprays and CHX showed a significant reduction of total facultative bacteria, oral streptococci and S. mutans on toothbrush when compared with distilled water. From our preliminary study, five oral spray formulations (6\% MO, 10\% MO, 13\% MO, 4\% MLO, 8\% MLO) successfully inhibited biofilm formation of $S$. mutans (ATCC 25175) in vitro. This study confirmed that three oral spray formulations (6\% MO, 10\% MO, $13 \% \mathrm{MO}$ ) effectively reduced facultative bacteria, oral streptococci, and S. mutans and was not significantly different from a gold standard antibacterial agent $(0.12 \% \mathrm{CHX})$ when spraying and left for $2 \mathrm{~h}$.

$\mathrm{CHX}$ was ranked as a gold standard antibacterial agent effective in reducing most bacteria on toothbrushes. Likewise, this study also show the effectiveness of CHX in a spray form ${ }^{16,20-24,35}$. Nevertheless, CHX is an antiseptic agent which effectively killed bacteria by penetrating into cell cytoplasm and lyse cell component ${ }^{36}$. Previous report showed that bacteria might developed a resistant mechanism, if used for a long time. Most researchers are trying to use herbal extraction as an alternative ${ }^{36,37}$. The mechanism by which essential oils inhibits biofilm formation is unknown. It has been proposed however that it could inhibit bacterial growth, acid production, or substrate adhesion. The active ingredients that have an antibacterial property in $C$. hystrix essential oils are $\alpha$-terpineol and citronellal, but their mechanism of inhibitory effect is unknown. However, there are other ingredients that have a bactericidal effect on $S$. mutans such as tt-farnesol. It has no bactericidal effect directly, but it interferes with the adhesion and polysaccharide production that relates to the biofilm formation ${ }^{35}$. The hydrophobicity of essential oils might enable them to partition the lipid component of bacterial cell membranes, rendering them permeable and leading to leakage of bacterial cell contents. As the mechanism of $C$. hystrix essential oil is still unclear, further study would be needed.

Acknowledgements: This project was partially supported by the Faculty of Dentistry, Mahidol University. The authors would like to thank Suan Missakawan school, Bangkok, Thailand for generously giving permission to conduct this study and Mr Artit Khlao-pimai for helping with microbiology procedures.

\section{REFERENCES}

1. Dental Health Division Ministry of Public Health Thailand (2007) The 6th National Dental Health Status Survey, 2006-2007. Nonthaburi: Dental Health Division.

2. Evans CA, Kleinman DV (2000) The surgeon general's report on America's oral health: opportunities for the dental profession. J Am Dent Assoc 131, 1721-8.

3. Acs G, Shulman R, Ng MW, Chussid S (1999) The effect of dental rehabilitation on the body weight of children with early childhood caries. Pediatr Dent 21, 109-13.

4. Tanzer JM, Livingston J, Thompson AM (2001) The microbiology of primary dental caries in humans. $J$ Dent Educ 65, 1028-37.

5. Marsh PD (2004) Dental plaque as a microbial biofilm. Caries Res 38, 204-11.

6. Featherstone JDB (2004) The continuum of dental caries-Evidence for a dynamic disease process. $J$ Dent Res 83, C39-42.

7. Berkowitz RJ (2006) Mutans streptococci: Acquisition and transmission. Pediatr Dent 28, 106-9.

8. Mitrakul K, Asvanud Y, Vongsavan K (2011) Prevalence of five biofilm-related oral streptococci species from plaque. $J$ Clin Pediatr Dent 36, 161-6.

9. Mitrakul K, Vongsavan K, Suratanachaikul P (2013) Prevalence of Streptococcus mutans and Lactobacillus fermentum and their association with caries and dietary habits in preschool Thai children. Eur Arch Paediatr Dent 14, 83-7.

10. Okada M, Soda Y, Hayashi F, Doi T, Suzuki J, Miura K, Kozai K (2002) PCR detection of Streptococcus mutans and $S$. sobrinus in dental plaque samples from Japanese pre-school children. J Med Microbiol 51, 443-7.

11. Ayşegül O, Elgin IE, Gulcin A, Nedim S (2007) The efficacy of chlorhexidine spraying vs mouthwash in 
the microbial contamination of child toothbrushes. $J$ Dent Child 74, 177-81.

12. Bhat SS, Hegde KS, George RM (2003) Microbial contamination of tooth brushes and their decontamination. J Indian Soc Pedod Prev Dent 21, 108-12.

13. Efstratiou M, Papaioannou W, Nakou M, Ktenas E, Vrotsos IA, Panis V (2007) Contamination of a toothbrush with antibacterial properties by oral microorganisms. $J$ Dent 35, 331-7.

14. Macari S, Ito IY, da Silva RAB, da Silva LAB, Garcia de Paula-Silva FW, Nelson-Filho P (2011) Efficacy of antimicrobial sprays for disinfection of children's toothbrushes-a randomized clinical trial. RPG Rev Pós-Grad 18, 8-12.

15. Neal PR, Rippin JW (2003) The efficacy of a toothbrush disinfectant spraying - an in vitro study. J Dent 31, 153-7.

16. Glass RT, Carson SR, Barker RL, Peiper SC, Shapiro $S$ (1994) Detection of HIV proviral DNA on toothbrushes: a preliminary study. J Okla Dent Assoc 84, 17-20.

17. Beneduce C, Baxter KA, Bowman J, Haines M, Andreana S (2010) Germicidal activity of antimicrobials and VIOlight personal travel toothbrush sanitizer: an in vitro study. $J$ Dent $38,621-5$.

18. Mehta A, Sequeira PS, Bhat G (2007) Bacterial contamination and decontamination of toothbrushes after use. New York State Dent J 73, 20-2.

19. Bezirtzoglou E, Cretoiu SM, Moldoveanu M, Alexopoulos A, Lazar V, Nakou M (2008) A quantitative approach to the effectiveness of ozone against microbiota organisms colonizing toothbrushes. J Dent 36, 600-5.

20. Caudry SD, Klitorinos A, Chan ECS (1995) Contaminated toothbrushes and their disinfection. J Can Dent Assoc 61, 511-6.

21. Malmberg E, Birkhed D, Norvenius G, Norén JG, Dahlén G (1994) Microorganisms on toothbrushes at day-care centers. Acta Odontol Scand 52, 93-8.

22. Nelson-Filho P, Faria G, da Silva RA, Rossi MA, Ito IY (2006) Evaluation of the contamination and disinfection methods of toothbrushes used by 24- to 48month-old children. J Dent Child 73, 152-8.

23. Sato S, Pedrazzi V, Guimarães Lara EH, Panzeri H, Ferreira de Albuquerque R Jr, Ito IY (2005) Antimicrobial spray for toothbrush disinfection: an in vivo evaluation. Quintessence Int 36, 812-6.

24. Galvão LC, Furletti VF, Bersan SM, da Cunha MG, Ruiz AL, de Carvalho JE (2012) Antimicrobial activity of essential oils against Streptococcus mutans and their antiproliferative effects. Evid Based Complement Altern Med 2012, ID 751435.

25. Kim JE, Kim HE, Hwang JK, Lee HJ, Kwon HK, Kim BI (2008) Antibacterial characteristics of Curcuma xanthorrhiza extract on Streptococcus mutans biofilm. $J$ Microbiol 46, 228-32.

26. Lee DH, Seo BR, Kim HY, Gum GC, Yu HH, You HK,
Kang TH, You YO (2011) Inhibitory effect of Aralia continentalis on the cariogenic properties of Streptococcus mutans. $J$ Ethnopharmacol 137, 979-84.

27. Nassar HM, Li M, Gregory RL (2012) Effect of honey on Streptococcus mutans growth and biofilm formation. Appl Environ Microbiol 78, 536-40.

28. Srisukh V, Tribuddharat C, Nukoolkarn V, Bunyapraphatsara N, Chokephaibulkit K, Phoomniyom S, Chuanphung S, Srifuengfung S (2012) Antibacterial activity of essential oils from Citrus hystrix (makrut lime) against respiratory tract pathogens. Sci Asia 38, 212-7.

29. Srisukh V, Tungrugsasut W, Anantapong M, Chutipaijit U, Bunyapraphatsara N, Pongpan A (2006) Readily-dissolved edible herbal film for suppression of bad breath. Thai $J$ Phytopharm 13, 1-15.

30. Ismail AI (1998) Prevention of early childhood caries. Community Dent Oral Epidemiol 26 (Suppl.), 49-61.

31. Greene JC, Vermillion JR (1994) The Simplified Oral Hygiene Index. $J$ Am Dent Assoc 68, 7-13.

32. Cascaes AM, Peres KG, Peres MA, Demarco FF, Santos I, Matijasevich A, Barros AJD (2011) Validity of 5 -year-old children's oral hygiene pattern referred by mothers. Rev Saúde Pública 45, 668-75.

33. Saravia ME, Nelson-Filho P, Silva RAB, De Rossi A, Faria G, Silva LAB, Emilson CG (2013) Recovery of mutans streptococci on MSB, SB-20 and SB-20M agar media. Arch Oral Biol 58, 311-6.

34. Kozai K, Iwai T, Miura K (1989) Residual contamination of toothbrushes by microorganisms. J Dent Child $56,201-4$.

35. van Rijkom HM, Truin GJ, van't Hof MA (1996) A meta-analysis of clinical studies on the caries-inhibiting effect of chlorhexidine treatment. J Dent Res $\mathbf{7 5}$, 790-5.

36. Komiyama EY, Back-Brito GN, Balducci I, Koga-Ito CY (2010) Evaluation of alternative methods for the disinfection of toothbrushes. Braz Oral Res 24, 28-33.

37. Svanberg M (1978) Contamination of toothpaste and toothbrush by Streptococcus mutans. Scand J Dent Res 86, 412-4. 